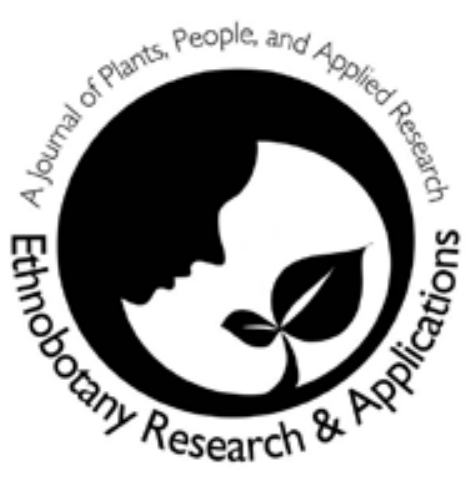

\title{
"Modern Linnaeus": A class exercise on plant nomenclature and taxonomy in comparison with a previous experiment
}

\author{
V. Savo, S. Bisceglie, G. Caneva, A. Kumbaric, \\ W.C. McClatchey and D. Reedy
}

\section{Education}

\begin{abstract}
Ethno-classification is a science dealing with a search for order, or a pattern, in the ways in which people name and categorize plants and animals. An experiment was conducted in the Botany class during the 2008-2009 academic year at the University of Roma Tre to collect data on the naming and classifying process of students not aware of the Linnaean system of classification. Forty plant specimens were shown to students who were divided into small groups and asked to name and classify the plants as they like. This paper shows the results of this experiment which was inspired by a very similar class exercise conducted at the University of Hawai i at Mānoa during the 2007-2008 Fall semester. Differences and similarities between the two experiences are analyzed here. The hypothesis tested is if the naming and classification process may be influenced by differences in language or culture. The use of binomial terms for plant names was predominant in both experiments even if the Italian language construction may have affected this result reducing the related percentage. Plant names are mainly constructed using morphological features of the specimen, among which color prevailed. This same result was observed in Hawai'i. Some differences were highlighted in the percentage of used terms, which may sometimes be traced back to experimental settings, while the overall results of the experiments are very similar.
\end{abstract}

\section{Introduction}

In ethnobiology at least two major questions may be recognized: the first question is about the way and how human societies use nature. The second one is fundamentally cognitive and asks "How and in what ways do human societies view nature? And subsequently, why do human societies classify nature in the ways they do? (Berlin 1992). These two last questions were at the basis of re- search on folk systematics, which is defined as the "field of study concerned with the elucidation of those general principles which underline prescientific man's classification, naming, and identification of living things" (Berlin 1973).

Many research projects have been focused on ethno-classification (Berlin 1973, 1992, Berlin et al. 1968, Diamond 1966, Dwyer 2005, Maddalon 1998, Trumper et al. 1999) and specifically were concerned with a search for order, or pattern, in the ways in which people name and categorize the living worlds that they experience (Conklin 1969, Dwyer 2005). These observations addressed both studies of ethno-classification of pre-scientific societies (Berlin et al. 1968, 1981, Bulmer 1967) and of identification and categorization systems in modern settings using plants or animals (Boster 1987, Breda 1995, Lau et al. 2009, Trumper \& Vigolo 1995). The main hypothesis shared by these two different kinds of studies is that there should be no difference, or at least slight differences, in the way humans, in general, order the world they experience. In fact, according to Boster (1987) the recognition of the pattern of

\section{Correspondence}

V. Savo, S. Bisceglie, G. Caneva, A. Kumbaric, Department of Environmental Biology, University Roma Tre, Viale Marconi 446, 00146, Rome, ITALY.

W.C. McClatchey, D. Reedy, Department of Botany, University of Hawai i at Mānoa, 3190 Maile Way, 101, Honolulu, Hawai' i/ Botanical Research Institute of Texas, 1700 N. University Avenue, Fort Worth, Texas, U.S.A.

Ethnobotany Research \& Applications 9:217-233 (2011)

Published: May 17, 2011 
resemblance between organisms does not seem to depend on formal training in taxonomy, intimate knowledge of the organisms, or possession of named categories for the specimens. Moreover, studies of the nature of folk biological nomenclature reveal that the naming of plants and animals in folk systematics is essentially identical in all languages and can be described by a small number of nomenclatural principles (Berlin 1973).

Languages have different structures as for example Italian is an inflexive language and English is an isolating language. However, it is possible to structure the same phrase in multiple ways within the same language [and the study that address this question deals with language use (Biber et al. 1998)]. This paper will analyze the use of language and the concepts that are beyond words. An analysis of language structure is beyond the scope of this paper, but we added the term class "composed terms" in order to solve problems of comparisons with agglutinative languages or other language structures.

Folk biological classification is based on recognition of natural discontinuities in the biological world that are considered to be similar or different because of gross, readily perceivable characteristics of form (Berlin 1973). Only rarely classification is based primarily on functional considerations of the organisms involved, such as for example, their cultural utility (Berlin 1973).

It has been observed that human groups order the diversity of plants and animals in their environments by grouping them into labeled categories of greater and lesser inclusiveness (Brown 1977). These categories are organized into a taxonomic hierarchy (Berlin et al. 1973, Kay 1971) that consists of a small number of folk biological ranks (Berlin 1978). The unique beginner is a distinctive category in that it has but one member, that being the taxon which includes all other taxa (e.g., plants). Members of the category life forms represent the broadest, most encompassing classification of organisms into groups that are apparently easily recognized on the basis of numerous gross morphological characters (Brown 1977). Taxa of this category are invariably few in number (Berlin 1973). The generic rank provides the core of the entire folk biological taxonomy (Berlin 1973). At this rank, plants appear perceptually most distinct to the human classifier. At subgeneric ranks, specific and varietal taxa appear to gain their distinctiveness in terms of cultural utility. Conversely, suprageneric categories are not always named (Berlin 1978).

These findings support the hypothesis by which the formal Linnaean taxonomy probably has codified a system of nomenclature present in the folk systematics of the earliest prescientific man (Raven et al. 1971). Moreover, it is worth noting that some authors (e.g., Boster 1987) have presented evidence of a collective understanding that is not limited to a particular collection of human beings. People have come to share an understanding with others by directly observing the world rather than by learning from others. This is critical since an important function of any nomenclature system is to provide a universal way for users to communicate effectively about things. Likewise, people of the same cultural group need to adhere to a consistent naming system to prevent confusion within the group (Lau et al. 2009). Moreover, plants and animals have a physical nature but also an undeniable symbolic value for people and their use by humans is strictly related to culture, environment and historical periods (Breda 1995, Maddalon 1998). While this theory is interesting, evaluating it in the real world is challenging.

In order to test some of these theories, a simple class exercise involving a group of students of the first year of university (Botany Course, Biology Department at the University Roma Tre during the 2008/2009 academic year) was planned in order to explore their cognitive pattern in naming and categorizing some plant specimens. The idea for this experiment arises from an open invitation expressed in Lau et al. (2009) where a similar experiment was conducted at the University of Hawai i at Mānoa that is analyzed below. The first aim of this experience was to increase the amount of data that could be useful to understand if a universal pattern in the naming and categorization of things may exist. The second aim of this exercise was to assess if there may be differences in this pattern that may be based on cultural or linguistic grounds.

\section{Methods}

During the Botany course of the academic year 20082009 a class exercise on plant nomenclature and classification was set out in a standard classroom. Students participating at the experiment were in total 42 (29 female and 13 male). The majority of students was at his/her first year of university and they were mainly 19-20 years old. Students were attending their first botany class and they were not likely aware of the Linnean classification or of the scientific naming of plants. Students were asked to name and categorize 40 plant materials (see Appendix 1) avoiding the use of common plant names and, after that, to group these plants into up to six categories. Each participant was asked to give consent to be photographed during the experiment. The inspiration for this experiment comes from Lau et al. (2009), but it was not possible to re-create the same experimental conditions (lab environment) nor to find all of the same plant species that were used in the Hawai i experiment. The list of plant species used in that experiment could be found in Lau et al., 2009, which is an open access article available on the web. Plant materials were selected, as in Hawai i, to include a broad range of texture, shapes and colors. We used plants with and without flowers, plants with thorns, plant materials with hairy leaves, with small, big or very colored flowers, aromatic plants, fruits or food plants. For the experiment, native, exotic, wild or cultivated plants were used, 


\section{Savo et al. - "Modern Linnaeus": A class exercise on plant nomenclature and 219 taxonomy in comparison with a previous experiment}

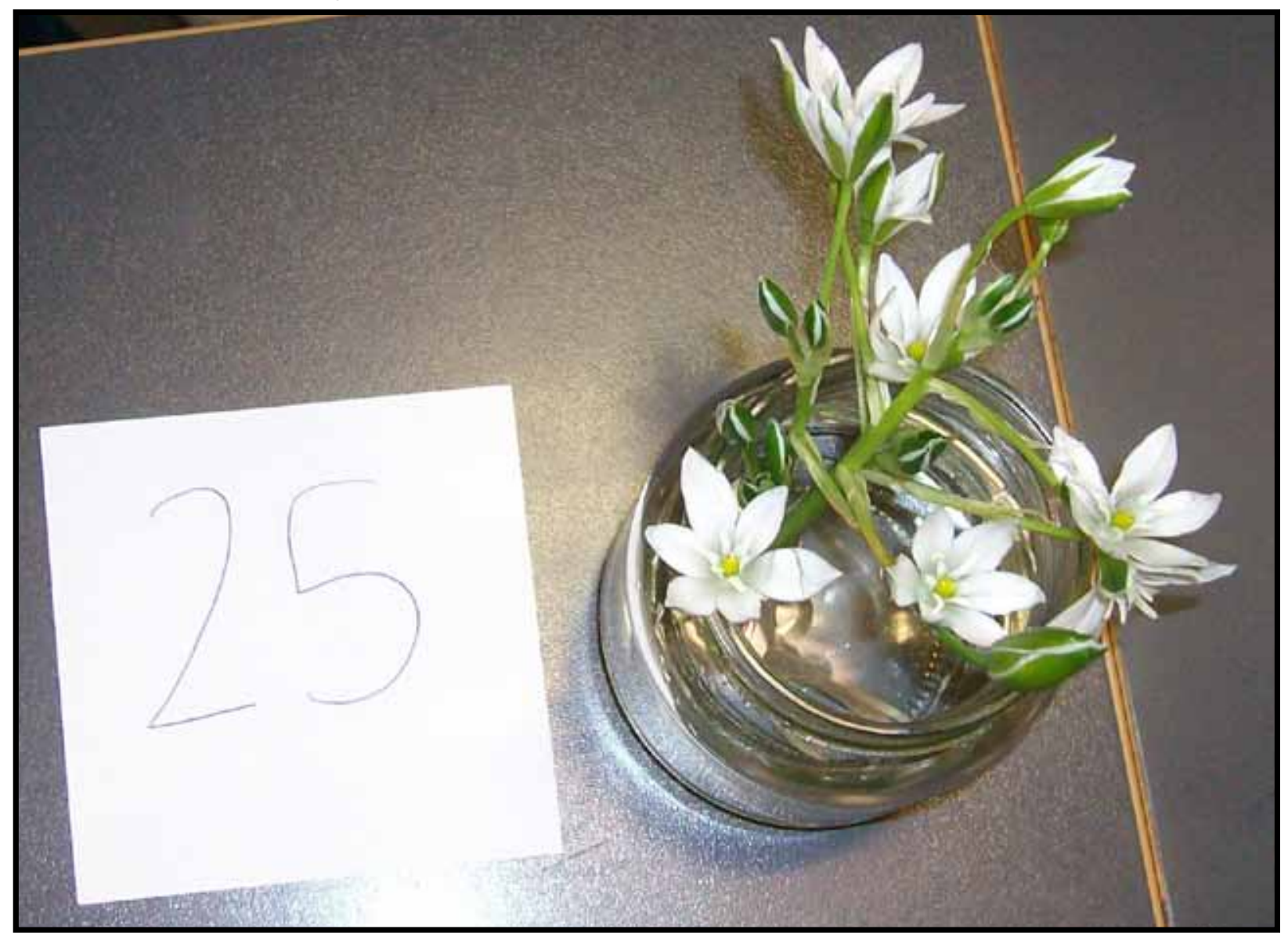

Figure 1. Plant specimen (Ornithogalum umbellatum L.) in a jar used in a class exercise on plant nomenclature in Rome, Italy.

but these should be familiar to the students since they are common in urban parks or markets. Species used in both experiments were: Solanum melongena L., Mentha spp., Solanum tuberosum L., and Brassica oleracea L. (with different varieties). Plants were collected within a couple of hours before the experiment in the urban park "Villa Doria Pamphilj", in Rome, or bought in a supermarket near the University (as in the case of $S$. tuberosum and $S$. melongena). Specimens were mostly put in jars filled with water (Figure 1); only some plants and the fruits and tubers were simply put on the class desks to make them easier to handle. All of the plants were set randomly on the class desks in nine rows and each plant was given a number, written down on a piece of paper and displayed near the specimen. Students were free to start the naming process wherever they desired (this was decided in order to avoid lines at the first plants and to keep students more separated in order to avoid as much as possible a reciprocal influence in the naming process).

Plant species were identified following the "Flora d'Italia" (Pignatti 2003) and "The European Garden Flora (Walters et al. 1986-2000). Their scientific names were updated us- ing "An Annotated Checklist of Italian Flora" (Conti et al. 2005) and "Integrazioni alla Checklist della flora vascolare italiana" (Conti et al. 2007) and then the Tropicos Database (Tropicos.org 2009). The names of plant species used in this experiment are listed in Appendix 1. Afterwards, plants were dried and made into herbarium specimens and deposited at the Herbarium of the University Roma Tre (URT) (Holmgren \& Holmgren 1998).

A stack of colored paper was given to each group of students with directions to use these to write down the number assigned to each plant and the name the group decided to give it. It was made clear that the point was not to test their ability to apply actual common or scientific names to the plants but to develop a meaningful system for naming the plants that they could use themselves (Lau et al. 2009). There were no figures on the walls or other visual stimuli around the class, allowing the students to focus on the experiment plants. The use of a simple classroom allowed us to eliminate external and environmental influences. The second phase of this experiment was the categorization of the named plants: after completing the naming procedure, each group was given paper 
to name the categories for their plants. They were asked to divide the plants into categories according to their personal classification systems and to assign a name to these categories. The responses were collected after students completed the exercise. Data were computerized in an Excel worksheet and analyzed. Plant and category names were analyzed using different dictionaries as the students used mainly Italian (Garzanti Linguistica online, Treccani Dizionario Enciclopedia online) but also Italian slang (Slangopedia, Italian Slang Dictionary online), Latin (Castiglioni \& Mariotti 1996), ancient Greek (Rocci 2002) and English (Merriam-Webster Online Dictionary). Terms used both to name plants and categories were counted in order to determine if names were mainly monomial, binomial, etc. Afterwards, each term was assigned to a category of meaning (for the definition of these categories see Appendix 2). When a word could have more than one meaning, the first meaning given by the dictionary was preferred (as for example salmon, Animal/Color). In just a few cases we gave priority to a secondary meaning if it was plant-related. Even though it has been recognized that an "understanding of the structure of a particular semantic domain may be obscured if one focuses solely on lexically labeled units" (Berlin et al. 1968), we decided to make an analysis that is term-based and each word was considered separately. We used both a smaller group of term categories and the same term categories found in Lau et al. (2009): in the first analysis we re-grouped term categories in order to have two comparable sets of term categories. The smaller group of term categories includes categories of nouns that are referred to plants, animals and humans, events, places and uses of plants (objects, food, medicine). Thus these categories reflects a broad set of concepts that could be related to plants (e.g., place - place of gathering, event - flowering period or feasts, anima/human - similarity with other living beings, etc.). In the second case (same categories as in Lau et al. 2009), however, we had to add four new categories (Composed terms, Objects, Numbers, Pronouns Preposition and Adverbs) for plant names and plant category names as some terms used during our experiment did not fit into the categories used in Lau et al. (2009). In order to better explain our procedure we provide some examples below:

- Formica acquatica (acquatic ant) = animal + adjective;

- $\quad$ Acquatica (aquatic) $=$ adjective related to location;

- $\quad$ Milleaghi (one thousand needles) $=$ this is a composed term, since the correct form is mille aghi, so our classification was $=$ composed term (number + tools and utensils);

- Cardium Pitagorae (Latin) (Cuore di Pitagora in Italian) ("Pitagora's heart" in English) = animal human parts + names;
- Piante che stimolano il tatto (plants that stimulate the sense of touch) = this sentence includes a verb, so it was considered a phrase, and so our subsequent classification was $=$ phrase $($ plant types + verb + descriptive).

Comparing the names in Italian or Latin with their translations in English, is already evident that to formulate the same concept the structure of the sentence may be different.

Finally, terms in each category (adjectives, plant parts, etc.) were counted and data compared to the results obtained in Lau et al. (2009).

\section{Results}

The entire experiment lasted for two and a half hours to give all students the opportunity to study the plants and represent their different perceptions of organismic relationships in an explicit nomenclatural system (Boster 1987). Thus, all the groups (14) were able to complete the exercise (Figures 2, 3) leading to the collection of 560 plant names and to 85 plant categories (see supplementary Microsoft Excel spreadsheet, botany_segue_It_2009. $\mathrm{xls}$ ).

Table 1 reports the number of terms used for plant names and categories (counting or excluding the prepositions). We decided to make this distinction in order to maintain consistency within the comparison with the experiment done with English speakers. This is due to the structure of the Italian language. A translation of the same sentence (unghie di gatto, cat claws) is comprised of three words in Italian while in English this description is made up of two words. Making this distinction, there were up to 7 terms (or 5, excluding prepositions) for the names and up to 7 terms for categories (with or without preposition) (Table 1). Besides, in Lau et al. (2009) the number of terms used for plant and category names ranged from 1 to 12 and 1 to 5

Table 1. Number of terms used for naming and categorizing plants by students in a class exercise on plant nomenclature in Rome, Italy.

\begin{tabular}{|r|r|r|r|r|}
\hline \multirow{2}{*}{$\begin{array}{l}\text { Number } \\
\text { of terms }\end{array}$} & \multicolumn{3}{|l|}{ Names } & \multicolumn{2}{l|}{ Categories } \\
\cline { 2 - 5 } & $\begin{array}{l}\text { without } \\
\text { preposition }\end{array}$ & \multicolumn{1}{l}{$\begin{array}{l}\text { with } \\
\text { preposition }\end{array}$} & $\begin{array}{l}\text { without } \\
\text { preposition }\end{array}$ & $\begin{array}{l}\text { with } \\
\text { preposition }\end{array}$ \\
\hline 1 & $39.3 \%$ & $39.3 \%$ & $56.3 \%$ & $56.3 \%$ \\
\hline 2 & $49.6 \%$ & $40.0 \%$ & $24.6 \%$ & $21.6 \%$ \\
\hline 3 & $7.9 \%$ & $14.8 \%$ & $7.7 \%$ & $7.5 \%$ \\
\hline 4 & $2.5 \%$ & $4.8 \%$ & $2.3 \%$ & $5.5 \%$ \\
\hline 5 & $0.7 \%$ & $0.5 \%$ & $5.7 \%$ & $5.7 \%$ \\
\hline 6 & $0.0 \%$ & $0.4 \%$ & $1.3 \%$ & $1.3 \%$ \\
\hline 7 & $0.0 \%$ & $0.2 \%$ & $2.1 \%$ & $2.1 \%$ \\
\hline
\end{tabular}




\section{Savo et al. - "Modern Linnaeus": A class exercise on plant nomenclature and 221 taxonomy in comparison with a previous experiment}

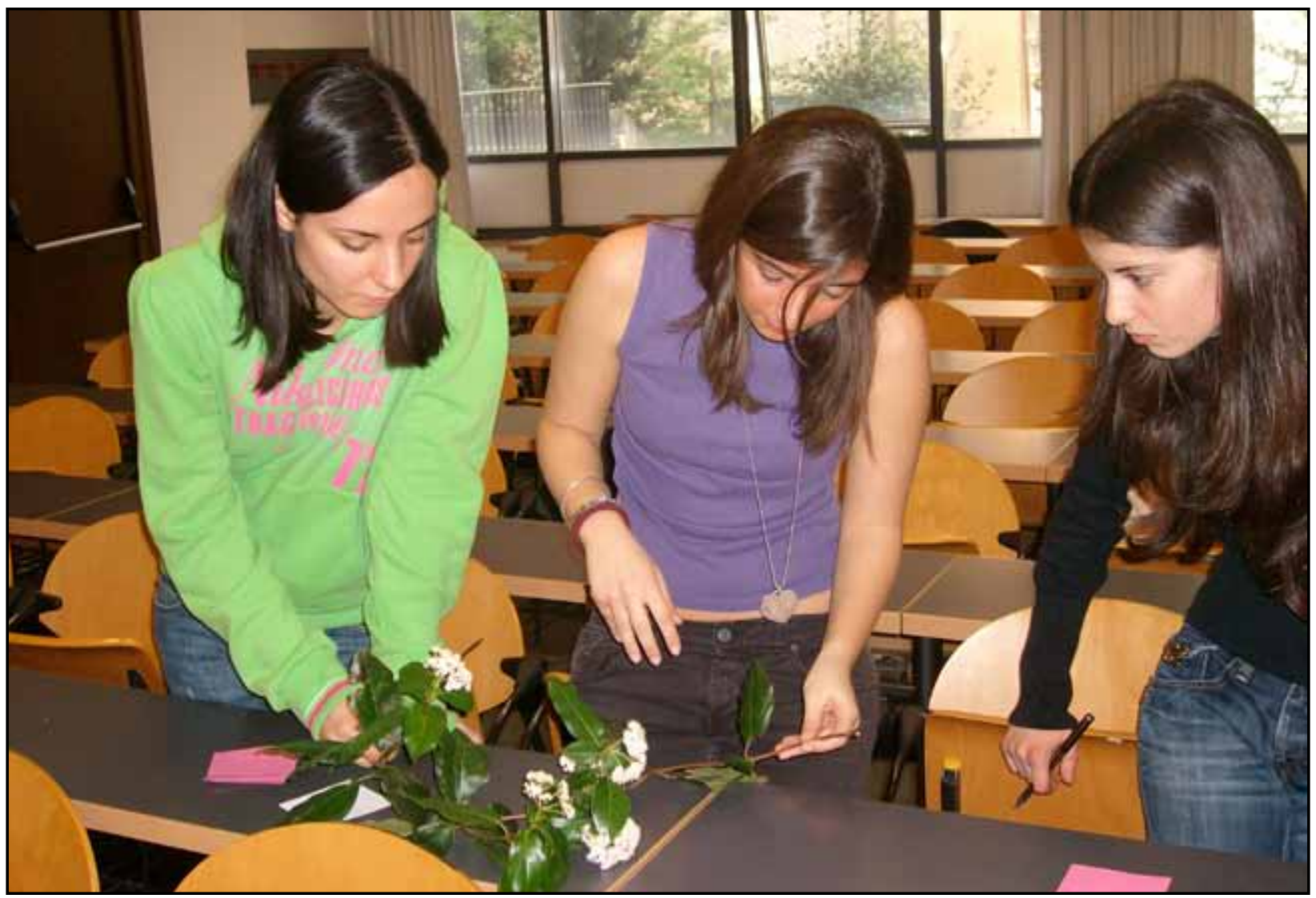

Figure 2. A group of students observing and naming a plant specimen in a class exercise on plant nomenclature in Rome, Italy.

respectively. The comparison between these sets of data is reported in Table 2.

Table 2. Number of terms used for naming and categorizing plants in comparing present research from Rome, Italy to Lau et al. (2009) from Hawai i.

\begin{tabular}{|r|r|r|r|r|}
\hline \multirow{2}{*}{$\begin{array}{l}\text { Number } \\
\text { of terms }\end{array}$} & \multicolumn{2}{|l|}{ Names \% } & \multicolumn{2}{l|}{ Categories\% } \\
\cline { 2 - 5 } & $\begin{array}{l}\text { (Lau et } \\
\text { al. 2009) }\end{array}$ & $\begin{array}{l}\text { Present } \\
\text { research }\end{array}$ & $\begin{array}{l}\text { (Lau et } \\
\text { al. 2009) }\end{array}$ & $\begin{array}{l}\text { Present } \\
\text { research }\end{array}$ \\
\hline 1 & $24.8 \%$ & $39.3 \%$ & $60.5 \%$ & $56.3 \%$ \\
\hline 2 & $51.6 \%$ & $49.6 \%$ & $31.9 \%$ & $24.6 \%$ \\
\hline 3 & $15.8 \%$ & $7.9 \%$ & $5.9 \%$ & $7.7 \%$ \\
\hline 4 & $4.3 \%$ & $2.5 \%$ & $1.3 \%$ & $2.3 \%$ \\
\hline 5 & $1.3 \%$ & $0.7 \%$ & $0.4 \%$ & $5.7 \%$ \\
\hline 6 & $1.1 \%$ & $0.0 \%$ & $0.0 \%$ & $1.3 \%$ \\
\hline 7 & $0.5 \%$ & $0.0 \%$ & $0.0 \%$ & $2.1 \%$ \\
\hline 8 & $0.2 \%$ & $0.0 \%$ & $0.0 \%$ & $0.0 \%$ \\
\hline 9 & $0.2 \%$ & $0.0 \%$ & $0.0 \%$ & $0.0 \%$ \\
\hline 10 & $0.3 \%$ & $0.0 \%$ & $0.0 \%$ & $0.0 \%$ \\
\hline 11 & $0.0 \%$ & $0.0 \%$ & $0.0 \%$ & $0.0 \%$ \\
\hline 12 & $0.1 \%$ & $0.0 \%$ & $0.0 \%$ & $0.0 \%$ \\
\hline
\end{tabular}

1. For plant names Mann-Whitney Test $-U=56$
Plant names, if without prepositions, are mainly binomial $(49.6 \%)$ followed by the monomial terms $(39.3 \%)$. Only a small percentage of names contain three or more terms $(11 \%)$. On the other hand, if prepositions are included in the count of terms, the result changes consistently: the binomial names $(40 \%)$ are almost in the same percentage of monomial ones $(39.3 \%)$ and the percentage of names with three terms is higher (14.8\%). Besides, the category names are not as influenced by the presence of prepositions as the monomial form $(56.3 \%)$ is in the prevailing one. The percentages of binomial terms in the category names are $21.6 \%$ with prepositions and $24.6 \%$ without, respectively. Category names with a higher number of terms are pretty common as some groups used a complex system of classification.

Data presented in this paper are more consistent ${ }^{1}$ with data from Lau et al. (2009), if we consider in the comparison names and category names without prepositions. In this way, binomial terms are predominant for the plant names while monomial terms are predominant for the category names. This same result, at least for plant names, has been reported in other studies: In fact, it has been observed that linguistically, the structure of specific names in folk systematics is regularly binomial (Berlin 1973). 


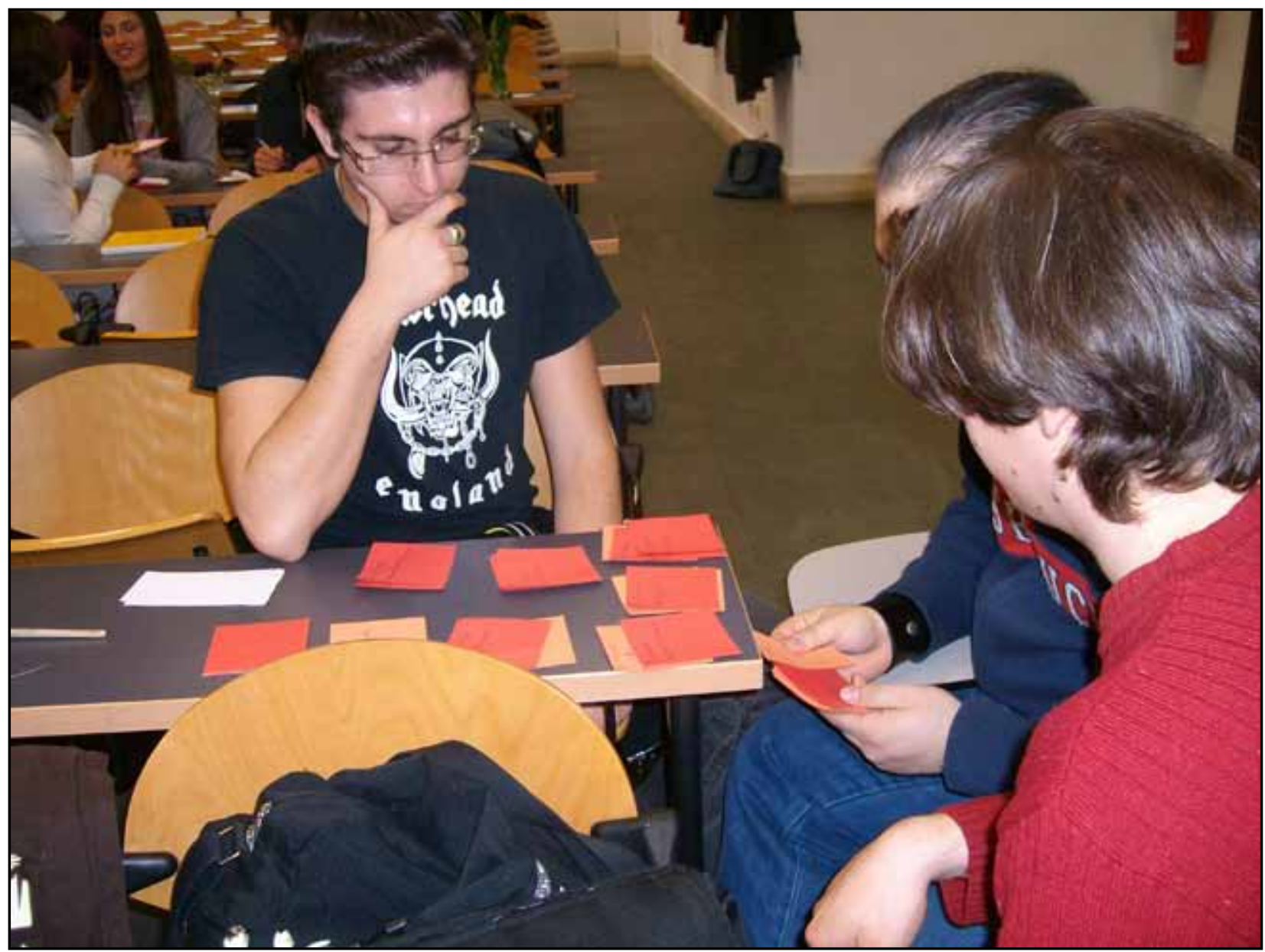

Figure 3. Students deciding the categories of plants in a class exercise on plant nomenclature in Rome, Italy.

The following step was to subdivide terms in different term type categories both considering pretty general term categories and the categories used in Lau et al. (2009), with the inclusion of four new term type categories (Composed verbs). The analysis of the obtained percentages and their comparison with the above mentioned paper is shown in Table 3 regarding plant names and in Table 4 regarding the category names. terms, Objects, Numbers, Pronouns Preposition and Ad-

Table 3. The percentage of plant names for each specific term type category comparing the present research from Rome, Italy to Lau et al. (2009) from Hawai'i. N.A. indicates that no terms of that category were used.

\begin{tabular}{|l|r|r|l|r|r|}
\hline General term type category & $\begin{array}{l}\text { Present } \\
\text { research }\end{array}$ & $\begin{array}{l}\text { Lau et al. } \\
\text { (2009) }\end{array}$ & $\begin{array}{l}\text { Specific term type } \\
\text { category of plant names }\end{array}$ & $\begin{array}{l}\text { Present } \\
\text { research }\end{array}$ & $\begin{array}{l}\text { Lau et al. } \\
\text { (2009) }\end{array}$ \\
\hline Adjectives & $35.56 \%$ & $42.6 \%$ & Adjectives & $35.56 \%$ & $42.6 \%$ \\
\hline Artificial objects & $16.55 \%$ & $16.2 \%$ & Objects & $9.86 \%$ & $I / I$ \\
\cline { 4 - 6 } & & Tools and utensils & $3.39 \%$ & $7.1 \%$ \\
\cline { 4 - 6 } & & Cosmetics and toiletries & $1.10 \%$ & $0.4 \%$ \\
\cline { 4 - 6 } & & $\begin{array}{l}\text { Constructions, inventions } \\
\text { and technologies }\end{array}$ & $1.00 \%$ & $1.6 \%$ \\
\cline { 4 - 6 } & & Fabrics & $0.60 \%$ & $2.3 \%$ \\
\hline & & Musical instruments & $0.30 \%$ & $1.3 \%$ \\
\cline { 4 - 6 } & & Decorations & $0.20 \%$ & $0.9 \%$ \\
\cline { 4 - 6 } & & Explosives & $0.10 \%$ & $2.6 \%$ \\
\hline
\end{tabular}


Savo et al. - "Modern Linnaeus": A class exercise on plant nomenclature and 223 taxonomy in comparison with a previous experiment

\begin{tabular}{|c|c|c|c|c|c|}
\hline General term type category & $\begin{array}{l}\text { Present } \\
\text { research }\end{array}$ & $\begin{array}{l}\text { Lau et al. } \\
(2009)\end{array}$ & $\begin{array}{l}\text { Specific term type } \\
\text { category of plant names }\end{array}$ & $\begin{array}{l}\text { Present } \\
\text { research }\end{array}$ & $\begin{array}{l}\text { Lau et al. } \\
(2009)\end{array}$ \\
\hline \multirow[t]{3}{*}{ Animal/human related terms } & \multirow[t]{3}{*}{$11.76 \%$} & \multirow[t]{3}{*}{$26.3 \%$} & Animal/human parts & $6.08 \%$ & $10.2 \%$ \\
\hline & & & Animals & $3.49 \%$ & $8.7 \%$ \\
\hline & & & People & $2.19 \%$ & $7.4 \%$ \\
\hline \multirow[t]{3}{*}{ Plant related terms } & \multirow[t]{3}{*}{$6.88 \%$} & \multirow[t]{3}{*}{$35.8 \%$} & Plant parts & $3.29 \%$ & $24.9 \%$ \\
\hline & & & Plants & $2.89 \%$ & $7.7 \%$ \\
\hline & & & Plant types & $0.70 \%$ & $3.2 \%$ \\
\hline \multirow{8}{*}{$\begin{array}{l}\text { Terms related to } \\
\text { abstract concepts }\end{array}$} & \multirow[t]{8}{*}{$6.68 \%$} & \multirow[t]{8}{*}{$5.7 \%$} & Descriptives & $6.18 \%$ & $1.9 \%$ \\
\hline & & & Hairstyles & $0.40 \%$ & $0.7 \%$ \\
\hline & & & Art & $0.10 \%$ & $0.1 \%$ \\
\hline & & & Sports & N.A. & $1.7 \%$ \\
\hline & & & Experiences & N.A. & $0.8 \%$ \\
\hline & & & Vocations & N.A. & $0.3 \%$ \\
\hline & & & Sounds & N.A. & $0.1 \%$ \\
\hline & & & Military operations & N.A. & $0.1 \%$ \\
\hline Unknown & $5.68 \%$ & $6.5 \%$ & Unknown & $5.68 \%$ & $6.5 \%$ \\
\hline \multirow[t]{2}{*}{ Natural inanimate objects } & \multirow[t]{2}{*}{$5.18 \%$} & \multirow[t]{2}{*}{$7.8 \%$} & Natural inanimate objects & $5.18 \%$ & $6.2 \%$ \\
\hline & & & Excrement & N.A. & $1.6 \%$ \\
\hline Composed terms & $3.19 \%$ & III & Composed terms & $3.19 \%$ & 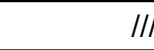 \\
\hline \multirow[t]{4}{*}{ Names } & \multirow[t]{4}{*}{$2.79 \%$} & \multirow[t]{4}{*}{$6.2 \%$} & Names & $2.69 \%$ & $5.9 \%$ \\
\hline & & & Song titles & $0.10 \%$ & $0.1 \%$ \\
\hline & & & Associations & N.A. & $0.1 \%$ \\
\hline & & & Titles & N.A. & N.A \\
\hline Places & $1.69 \%$ & $1.5 \%$ & Places & $1.69 \%$ & $1.5 \%$ \\
\hline $\begin{array}{l}\text { Food, beverages } \\
\text { and food plants }\end{array}$ & $1.49 \%$ & $10.2 \%$ & $\begin{array}{l}\text { Food, beverages } \\
\text { and food plants }\end{array}$ & $1.49 \%$ & $10.2 \%$ \\
\hline Actions (verbs) & $0.70 \%$ & $3.8 \%$ & Actions & $0.70 \%$ & $3.8 \%$ \\
\hline \multirow[t]{3}{*}{$\begin{array}{l}\text { Pronouns, Interjections, } \\
\text { Prepositions and Adverbs }\end{array}$} & \multirow[t]{3}{*}{$0.70 \%$} & \multirow[t]{3}{*}{$0.4 \%$} & $\begin{array}{l}\text { Pronouns, Preposition } \\
\text { and Adverbs }\end{array}$ & $0.50 \%$ & /II \\
\hline & & & Exclamations & $0.20 \%$ & $0.4 \%$ \\
\hline & & & Punctuation marks & N.A. & N.A. \\
\hline Numbers & $0.60 \%$ & III & Numbers & $0.60 \%$ & III \\
\hline $\begin{array}{l}\text { Medicine and Medical } \\
\text { conditions }\end{array}$ & $0.40 \%$ & $1.3 \%$ & $\begin{array}{l}\text { Medicine and Medical } \\
\text { conditions }\end{array}$ & $0.40 \%$ & $1.3 \%$ \\
\hline Events & $0.20 \%$ & $1.7 \%$ & Events & $0.20 \%$ & $1.7 \%$ \\
\hline Microorganisms & $0.10 \%$ & $0.1 \%$ & Microorganisms & $0.10 \%$ & $0.1 \%$ \\
\hline Phrases & N.A. & $4.0 \%$ & Phrases & N.A. & $4.0 \%$ \\
\hline
\end{tabular}

It would have been interesting to analyze the etymology of some terms in more detail in order to detect if there could be closer or more symbolic connections with the plants. However, this kind of analysis is beyond the scope of this article and it is often impossible to provide linguistic and etymological analysis of the names assigned to living beings, a fact that should not be surprising since such names are generally quite ancient (Berlin 1973). As for example, among the plants chosen for this experiment, Ocimum basilicum L. has been known since ancient Roman and Greek times and etymologically its name means "scented plant of kings" (Paolucci 1926), but no names given here refer to this meaning. 
Table 4. The percentage of plant category names for each specific term type category comparing the present research from Rome, Italy to Lau et al. (2009) from Hawai i. N.A. indicates that no terms of that category were used.

\begin{tabular}{|c|c|c|c|c|c|}
\hline General term type category & $\begin{array}{l}\text { Present } \\
\text { research }\end{array}$ & \begin{tabular}{|l|} 
Lau et \\
al. (2009)
\end{tabular} & $\begin{array}{l}\text { Specific term type } \\
\text { category of plant names }\end{array}$ & $\begin{array}{l}\text { Present } \\
\text { research }\end{array}$ & $\begin{array}{l}\text { Lau et al. } \\
(2009)\end{array}$ \\
\hline Adjectives & $45.8 \%$ & $41.8 \%$ & Adjectives & $45.8 \%$ & $41.8 \%$ \\
\hline \multirow[t]{3}{*}{ Plant related terms } & \multirow[t]{3}{*}{$18.2 \%$} & \multirow[t]{3}{*}{$36.1 \%$} & Plant parts & $12.0 \%$ & $26.5 \%$ \\
\hline & & & Plant types & $5.6 \%$ & $5.6 \%$ \\
\hline & & & Plants & $0.6 \%$ & $4.0 \%$ \\
\hline \multirow{8}{*}{$\begin{array}{l}\text { Terms related to } \\
\text { abstract concepts }\end{array}$} & \multirow[t]{8}{*}{$13.7 \%$} & \multirow[t]{8}{*}{$13.2 \%$} & Descriptives & $13.7 \%$ & $12.4 \%$ \\
\hline & & & Sports & N.A. & $0.8 \%$ \\
\hline & & & Hairstyles & N.A. & N.A. \\
\hline & & & Art & N.A. & N.A. \\
\hline & & & Experiences & N.A. & N.A. \\
\hline & & & Vocations & N.A. & N.A. \\
\hline & & & Sound & N.A. & N.A. \\
\hline & & & Military operations & N.A. & N.A. \\
\hline \multirow[t]{3}{*}{ Animal/human related terms } & \multirow[t]{3}{*}{$5.6 \%$} & \multirow{3}{*}{$5.6 \%$} & Animal/human parts & $4.5 \%$ & $1.6 \%$ \\
\hline & & & Animals & $1.1 \%$ & $3.2 \%$ \\
\hline & & & People & N.A. & $0.8 \%$ \\
\hline Places & $3.8 \%$ & $1.2 \%$ & Places & $3.8 \%$ & $1.2 \%$ \\
\hline Unknown & $3.2 \%$ & $8.0 \%$ & Unknown & $3.2 \%$ & $8.0 \%$ \\
\hline \multirow[t]{8}{*}{ Artificial objects } & \multirow[t]{8}{*}{$2.7 \%$} & \multirow[t]{8}{*}{$2.8 \%$} & Objects & $2.0 \%$ & III \\
\hline & & & Tools and utensils & $0.7 \%$ & $1.2 \%$ \\
\hline & & & Decorations & N.A. & $0.8 \%$ \\
\hline & & & Musical instruments & N.A. & $0.4 \%$ \\
\hline & & & Explosives & N.A. & $0.4 \%$ \\
\hline & & & Cosmetics and toiletries & N.A. & N.A. \\
\hline & & & $\begin{array}{l}\text { Constructions, inventions } \\
\text { and technologies }\end{array}$ & N.A. & N.A. \\
\hline & & & Fabrics & N.A. & N.A. \\
\hline Actions (verbs) & $2.5 \%$ & $2.4 \%$ & Actions (verbs) & $2.5 \%$ & $2.4 \%$ \\
\hline Phrases & $2.0 \%$ & $0.8 \%$ & Phrases & $2.0 \%$ & $0.8 \%$ \\
\hline \multirow[t]{2}{*}{ Natural inanimate objects } & \multirow[t]{2}{*}{$1.0 \%$} & \multirow[t]{2}{*}{$3.6 \%$} & Natural inanimate objects & $1.0 \%$ & $2.8 \%$ \\
\hline & & & Excrement & N.A. & $0.8 \%$ \\
\hline \multirow{3}{*}{$\begin{array}{l}\text { Pronouns, Interjections, } \\
\text { Prepositions and Adverbs }\end{array}$} & \multirow[t]{3}{*}{$0.9 \%$} & \multirow[t]{3}{*}{$0.4 \%$} & Pronouns preposition or adverbs & $0.9 \%$ & III \\
\hline & & & Punctuation marks & N.A. & $0.4 \%$ \\
\hline & & & Exclamations & N.A. & N.A. \\
\hline $\begin{array}{l}\text { Food, beverages } \\
\text { and food plants }\end{array}$ & $0.6 \%$ & $2.0 \%$ & Food, beverages and food plants & $0.6 \%$ & $2.0 \%$ \\
\hline \multirow[t]{4}{*}{ Names } & \multirow[t]{4}{*}{ N.A. } & \multirow[t]{4}{*}{$3.2 \%$} & Names & N.A. & $2.8 \%$ \\
\hline & & & Titles & N.A. & $0.4 \%$ \\
\hline & & & Song title & N.A. & N.A. \\
\hline & & & Associations & N.A. & N.A. \\
\hline Events & N.A. & $0.8 \%$ & Events & N.A. & $0.8 \%$ \\
\hline
\end{tabular}




\section{Savo et al. - "Modern Linnaeus": A class exercise on plant nomenclature and 225 taxonomy in comparison with a previous experiment}

\begin{tabular}{|l|r|r|l|r|r|}
\hline $\begin{array}{l}\text { Medicine and Medical } \\
\text { conditions }\end{array}$ & N.A. & N.A. & Medicine and Medical conditions & N.A. & N.A. \\
\hline Microorganisms & N.A. & N.A. & Microorganisms & N.A. & N.A. \\
\hline Numbers & N.A. & III & Numbers & N.A. & III \\
\hline Composed terms & N.A. & III & Composed terms & N.A. & III \\
\hline
\end{tabular}

In regards to the plant names, in this experiment, as well as in Lau et al. (2009), adjectives were the most used term type (35.52\%), while there are some differences between the two sets of experimental data considering other term categories. It has been observed that, often, names were composed of two parts, a noun and a descriptive (adjective or another noun) of some quality of the plant to which it refers. Terms related to plants were widely used in the Hawai i experiment $(35.8 \%)$ while this kind of term was used much less in Italy (6.88\%). In our experiment a high percentage of terms were included in the "artificial objects" category as well as in Lau et al. (2009). This category was not considered in that paper, but we re-grouped some specific categories (referred to Tools and utensils, Cosmetics and toiletries, Constructions, inventions and technologies, Fabrics, Musical instruments, Decorations, Explosives) into a broader category of "artificial objects". In general, in regards to plant names, a great diversity of used terms has been outlined, rather than a general prevalence of one or few categories above the others (as it happened in the Hawai' i experiment).

On the other hand, in analyzing the plant category names it has been observed that adjectives prevail in both data sets (Table 4). As regards the "plant part" and the "plants" terms there is a divergence: in Hawai' $i$ they were significantly more accustomed than in Italy to applying plant related terms. On the contrary, in Italy terms related to animals/humans were used much more often.

The majority of names were composed of a noun and an adjective: this same structure of plant names has been described within other research (Berlin 1978, Breda 1995, Hiepko 2006, Lau et al. 2009). Plant names of this experiment may be considered as specific names of plants sensu Berlin. Berlin (1973) pointed out that, formally, the specific name is modified by an adjective which usually designates some obvious morphological character of the plant class such as color, texture, size and location. Thus, the adjectives were analyzed and divided into categories of meaning, considering mainly these features (the categories are the same as Lau et al. (2009) (Table 5) with the addition of one category "Indefinable").

As regards the plant names the analysis of the adjectives which were used by students showed a prevalence of those related to the "color" feature. Even though, the adjectives related to shape, texture and the physical condition were also in high percentage. In Lau et al. (2009) the color attribute was the most used as well, but it was more widely used (43.3\%). In this last experience other features were significantly less important while in our experience the difference in percentage of the other adjective types was not so strong. We had to add an adjective type category, named "indefinable", as we were not able to include some adjectives in the categories found in Lau et al. (2009) as for example forestiero, foreign and improbabile, unlikely.

On the other hand, categories are mainly named and described by shape and secondly by size, color and texture features. Considering the adjectives used in the category names there are some differences between our experiment and the one carried out in Hawai' i: specifically, here the shape was retained as the most distinctive feature while in Lau et al. (2009) the "physical conditions" is the prevailing adjective type. Other adjectives were used almost in the same proportion excluding the category "feeling" that was rarely used in our experiment but not in the referring article. We had to add an adjective type category

Table 5. Adjective types in the names and categories and their relative frequency comparing the present research from Rome, Italy to Lau et al. (2009) from Hawai i. N.A. indicates that no terms of that category were used.

\begin{tabular}{|l|r|r|r|r|}
\hline \multirow{2}{*}{$\begin{array}{l}\text { Adjective } \\
\text { types }\end{array}$} & \multicolumn{2}{|l|}{ Names } & \multicolumn{2}{l|}{ Categories } \\
\cline { 2 - 5 } & $\begin{array}{l}\text { Present } \\
\text { research }\end{array}$ & $\begin{array}{l}\text { Lau et } \\
\text { al. (2009) }\end{array}$ & $\begin{array}{l}\text { Present } \\
\text { research }\end{array}$ & $\begin{array}{l}\text { Lau et } \\
\text { al. (2009) }\end{array}$ \\
\hline Color & $18.8 \%$ & $43.3 \%$ & $16.7 \%$ & $11.3 \%$ \\
\hline Shape & $15.7 \%$ & $6.7 \%$ & $29.2 \%$ & $6.6 \%$ \\
\hline Texture & $14.3 \%$ & $16.3 \%$ & $12.7 \%$ & $17.0 \%$ \\
\hline $\begin{array}{l}\text { Physical } \\
\text { condition }\end{array}$ & $12.3 \%$ & $5.7 \%$ & $2.7 \%$ & $30.2 \%$ \\
\hline Indefinable & $11.2 \%$ & $1 / I / /$ & $11.5 \%$ & $/ / I /$ \\
\hline Feeling & $6.4 \%$ & $4.3 \%$ & $0.7 \%$ & $11.3 \%$ \\
\hline Quantity & $4.8 \%$ & $3.7 \%$ & $2.5 \%$ & $2.8 \%$ \\
\hline Location & $4.5 \%$ & $0.2 \%$ & N.A. & $0.9 \%$ \\
\hline Smell & $3.3 \%$ & $1.5 \%$ & $3.9 \%$ & $0.9 \%$ \\
\hline Pattern & $3.1 \%$ & $3.5 \%$ & N.A. & $3.8 \%$ \\
\hline Size & $3.1 \%$ & $12.4 \%$ & $18.1 \%$ & $14.2 \%$ \\
\hline Taste & $1.7 \%$ & $2.0 \%$ & $2.0 \%$ & N.A. \\
\hline Ethnicity & $0.8 \%$ & $0.6 \%$ & N.A. & $0.9 \%$ \\
\hline
\end{tabular}


also for the category name, also named "indefinable" (for example for culinarie, gastronomical, Pitagoriane, related to Pythagoras, accorpate, joined).

The plant type terms were not so much used in our experiment both for plant and for category names (Table 6 ). However, we did a detailed analysis for these kinds of terms to complete the comparison of data with Lau et al. (2009). Leaves and flowers were the most capturing features in both experiments (considering plant names and category names). Fruit term types were not used as much maybe because there was a difference in fruit presence in plant specimens in the two experiments.

Among the plant name terms used in this experiment one of the most used was stella (star) which was applied 14 times in composing terms, by almost all groups for the description of different plants but especially Sherardia arvensis L. and Ornithogalum umbellatum L. Another repeated term was campanella (four), little bell, and campanellina (four), very little bell, used for Bellevalia romana Rchb. Other repeated terms, excluding plant part terms and colors, are the word starting with the prefix penta- (ten) meaning five, frusta meaning whip (six), girandola, pinwheel (five), farfalla, butterfly (five), spirale, spiral (four), luna, moon (four), and cervello, brain (three).

Berlin (1978) found out that the basic principles of classification of biological diversity appear to arise directly out of the recognition by man of groupings of plants and animals formed on the basis of visible similarities and differences as can be inferred from gross features of morphology and behavior. The students of the groups often used similar categories, or at least identified as discriminating similar features, and in particular shape, color and texture. In this

Table 6. Plant part types in the names and categories and their relative frequency comparing the present research from Rome, Italy to Lau et al. (2009) from Hawai'i.

\begin{tabular}{|l|r|r|r|r|}
\hline \multirow{2}{*}{$\begin{array}{l}\text { Plant } \\
\text { part }\end{array}$} & \multicolumn{2}{|l|}{ Names } & \multicolumn{2}{l|}{ Categories } \\
\cline { 2 - 5 } & $\begin{array}{l}\text { Present } \\
\text { research }\end{array}$ & $\begin{array}{l}\text { Lau et al. } \\
\text { (2009) }\end{array}$ & $\begin{array}{l}\text { Present } \\
\text { research }\end{array}$ & $\begin{array}{l}\text { Lau et al. } \\
\text { (2009) }\end{array}$ \\
\hline Leaf & $20.6 \%$ & $33.1 \%$ & $57.9 \%$ & $34.8 \%$ \\
\hline Flower & $20.6 \%$ & $31.1 \%$ & $38.3 \%$ & $28.8 \%$ \\
\hline Stem & $14.7 \%$ & $6.0 \%$ & $3.7 \%$ & $4.5 \%$ \\
\hline Thorn & $11.8 \%$ & $1.7 \%$ & N.A. & $1.5 \%$ \\
\hline Fruit & $8.8 \%$ & $19.9 \%$ & N.A. & $24.2 \%$ \\
\hline Bark & $8.8 \%$ & $0.3 \%$ & N.A. & N.A. \\
\hline Root & $5.9 \%$ & $1.3 \%$ & N.A. & $3.0 \%$ \\
\hline Branch & $2.9 \%$ & $3.6 \%$ & N.A. & $3.0 \%$ \\
\hline Seed & $2.9 \%$ & $2.3 \%$ & N.A. & N.A. \\
\hline Bud & $2.9 \%$ & $0.7 \%$ & N.A. & N.A. \\
\hline
\end{tabular}

experiment the location or habitat of the plants were rarely mentioned as plants were recognized in an indoor setting.

Some plants (S. tuberosum and B. oleracea var. gongylodes L.) were included by all of the students within the same plant category, while S. melongena was differentiated by the above mentioned plants only by a single group. Two other plants (Mentha suaveolens Ehrh. and O. basilicum) were classified within the same category by 12 out of 14 groups. No groups categorized all the Lamiaceae within the same category, while 10 groups categorized the two cabbages in the same category. Finally, in naming the cabbages, students used terms referring to the moon, the head and balls. It has been outlined that the objective pattern of similarity among organisms determines the basic structure of folk biological classifications and that alternative classifications are similar to the extent that the objective pattern is clear. Cultural transmission is apparently not a prerequisite to shared understanding (Boster 1987).

It has been observed that life-form terms seem to be implicational universals (when the occurrence of an item in languages implies the occurrence of another item or items but not vice versa) (Brown 1977). According to Brown (1977), there are generally five major life terms in languages (tree, herb, bush, grass, and vine) and they may also have a positive correlation with societal complexity and an association with the botanical species diversity. This correlation was also observed with the variety of colors used by a society (Brown 1977). In our case it is obviously not possible to analyze these correlations, but we tried to explore the occurrence of the life terms. We especially looked for life forms in the plant name list and in the category name list: the term albero/alberi (tree/trees) only occurs in the category names (twice, one category name) while the term erba (herb but also grass) does not occur in the plant name list nor in the category name list. The term arbusto/arbusti (bush/bushes) occurs only once in the plant name list. It is worth it to mention that herb and grass are expressed with the same term in Italian erba, but also weed may be expressed with the same term erba or with the term erbaccia (this last term was used once in the plant name list). However, Brown (1977) does not consider the term weed as a life term. It is interesting to note that the term pianta/piante (plant/plants) occurs once in the plant name list while it occurs 42 times (five category names) in the category name list.

This word, plant, which encompasses all botanical organisms, is considered as a "covert unique beginner" (Berlin et al. 1973, Brown 1974) in the sense that people can discriminate plants from animals but that does not mean that they make it taxonomically overt. However, the term plant is also commonly and widely used in a secondary sense to refer to all non-"tree" plants (Brown 1977, Buck 1949, Maddalon 1995). In Italian dialects, indeed, it usually refers to trees in contraposition of herbs as it denomi- 


\section{Savo et al. - "Modern Linnaeus": A class exercise on plant nomenclature and 227 taxonomy in comparison with a previous experiment}

nates a species with a distinct aerial stem and it is related to the verb "to plant" in contraposition to the verb "to seed" (Breda 1995). According to Berlin (1972) people living in complex societies tend to be rarely involved with the natural world, hence their knowledge of ethnobiology is seldom highly developed or particularly detailed. So it is more common to use life-form names rather than proper botanical terms (Brown 1977).

\section{Discussion}

This experiment allowed us to outline the different behavior and skills of students in an experiment which may be considered "unusual". Students were quite interested in this experiment and participated with great enthusiasm, staying after the end of the scheduled lecture to complete their tasks. Data collected gave us both quantitative and qualitative information on the nomenclature system of these "modern Linnaeus." A first interesting result concerns the structure of names and categories of plants: in fact, plant names are generally binomial, while category names are mainly monomial. This result is basically similar to the findings expressed in Lau et al. (2009). However, the comparison with that article was mainly related to the use of the same species and with the use of prepositions in Italian language. In fact, in English it is possible to express the same concept using two different constructions: Cat claws in fact may be also expressed as claws of cats while in Italian unghie di gatto may only be expressed with three terms. For this reason, terms were counted either considering or excluding prepositions, in order to keep data more comparable with those in English. Furthermore, it is worthwhile to mention that Hawai $i$ students preferred the binomial forms ${ }^{2}$ instead of using forms made with three terms may be considered evidence that the use of the binomial form is considered somehow the best or simpler form for naming plants. Even though the plant species used in the two experiments were different (although similar in features), the results are however, quite similar. This finding (on the preference of binomial forms in plant names) seems to increase data that support the hypothesis that certain attitudes of people in naming plants may be general as it has also highlighted in other studies (Berlin 1973). Moreover, the binomial names were mainly composed by a noun and an adjective as in other studies (Berlin 1978, Breda 1995, Hiepko 2006, Lau et al. 2009).

Considering the category names, monomial terms were most common. This result may indicate that students looked for a dominant feature for describing the category of plants. Nevertheless, with regards to category names, a strong influence on results by the presence or absence of prepositions was not observed (especially in the bino- mial terms). On the other hand, the use of long sentences has been observed as two groups used a complex system of classification implied in the name (they used a descriptive name with differential features of the plants).

Regarding the qualitative analysis, the meaning of used terms was analyzed and they were further divided into general categories and into the categories as reported in Lau et al. (2009). In comparison with that experience, some categories were used in both experiments, while others were added as the meaning of some terms was not classifiable with one of those categories, while some categories considered in Lau et al. (2009) were not used at all in our experiment. However, with few exceptions, the order of preferred terms for naming plants and categories is the same.

It was observed that students mainly used a deductive taxonomy (Beaucage 1987, Breda 1995) instead of an inductive taxonomy. In other words, students generally were inclined to create a classification system based only on the features of the specimens used in the experiment: they rarely considered general or intrinsic features, but mainly considered features in a comparative way (big/ small, considering the pool of specimens). In a few cases, however, the diagnostic features may be considered as intrinsic of the plant (resemblance of well defined objects, plants). Moreover, students considered as distinctive features, different and not homogenous characteristics both because some features were comparative and because they may be referred to more than one characteristic of the plant (some groups considered shape, smell and use features for discriminating categories). The fact that they rarely used an inductive taxonomy may be due to the fact that they experienced differences of only forty plants, so they had no necessity for more complicated taxonomic systems.

In comparison with the experiment carried out in Hawai $i$, we have outlined a decrease in percentage of terms related to plants or plant parts; this result may have different causes. First of all, students had no external visual stimulus (such as botany posters) that may evocate plants. Moreover, the specimens used in this experiment had to a lesser extent big flowers or plant parts with striking features.

Different groups of students often used similar categories, or at least identified as discriminating similar features: In fact, the recognition of the pattern of resemblance between organisms does not seem to depend on formal training in taxonomy, intimate knowledge of the organisms, or possession of named categories for the specimens (Boster 1987).

2. English has both choices because it is a language that is based on both French and German. Therefore, terms can be stated using Latin or Germanic constructions. Most students prefer binomials because they fit easier into the Germanic format and that is currently the dominat form of English. The Latin form of English is thought to sound "archaic" and students don't want to sound "old." However, if a student wants to sound like they are really well educated then they will use the Latin version. 
Even though more data and studies are needed, the results of this experiment seem to support the basic finding of other studies on folk biological classification: humans universally perceive the natural order in a similar way (Berlin 1973, Berlin et al. 1973, Boster et al. 1986, Bulmer 1967, Diamond 1966, Hunn 1975).

\section{Conclusions}

The major output of this experience was an increase of data related to studies on folk taxonomy. Moreover, this experience allowed us to compare the results of similar experiences in which students of different cultural backgrounds were involved. Differences may generally be attributed to the different linguistic construction of the Italian language even though the experimental settings may have generated other differences. Finally, it is worthwhile to mention that the Italian students used many different languages (Latin, ancient Greek, English and Italian slang). On the other hand, the common characteristics concern the prevailing use of a binomial term structure (noun + adjective) for the plant names. As regards the classification of plants, the category names were mainly binomial in both experiences, while the characteristics deemed most important by students in Italy were related to Shape in Italy and to Physical Conditions in Hawai i (somehow related to the form sensu latu). Some of these common features were also highlighted in studies dealing with folk classification systems.

Finally, this work highlights some differences limiting the kinds of words used, not in regards to the most used categories of terms but in regards to the less used category of terms. In fact, many categories of terms which were used in Lau et al. (2009) were not used at all in Italy, since in the analysis of terms meaning we had to introduce some new categories for Italy.

The fact that many elements are common (use of binomial terms for plant names made of a noun and an adjective, use of monomial terms for plant category names, the prevailing of terms related to morphological features of the plant) even though the plants used are different, may be considered as support for the theory that certain patterns in the plant naming process are not related to specific characteristics of the plants or students but are general. It would be interesting to repeat the same experiment using both the same plants and different plants (as long as the variety in the features of the specimens is kept comparable) in other parts of the world in order to increase the amount of available data on the fascinating topic of folk nomenclature and taxonomy.

The authors would like to invite researchers from other countries to develop the same experiment into their botany classes. Data based on experiences with students with different cultural backgrounds and language features would increase the knowledge on human categorization processes.

\section{Acknowledgements}

We thank the Spring 2009 Botany class at the University Roma Tre for their participation in this project.

\section{Literature Cited}

Beaucage, P. 1987. Catégories pratiques et taxonomie: Notes sur les classifications et les pratiques botaniques des Nahuas (Sierra Norte de Puebla, Mexique). Recherches amèrindiennes au Quebec. L'etniences, autres regards, autre mots 17(4):17-34.

Berlin, B. 1972. Speculations on the growth of ethnobotanical nomenclature. Language in Society 1:5186.

Berlin, B. 1973. Folk systematics in relation to biological classification and nomenclature. Annual Review of Ecology and Systematics 4:259-271.

Berlin, B. 1978. Ethnobiological classification. Pp. 9-26 in Cognition and Categorization. Edited by E. Rosch \& B.B. Lloyd. Lawrence Erlbaum Associates, Hillsdale, New Jersey.

Berlin, B. 1992. Ethnobiological Classification. Principles of categorization of plants and animals in traditional societies. Princeton University Press, Princeton, New Jersey.

Berlin, B., J. Boster \& J.P. O'Neill. 1981. The perceptual bases of ethnobiological classification: Evidence from Aguaruna Jivaro ornithology. Journal of Ethnobiology 1(1):95-108.

Berlin, B., D.E. Breedlove \& P.H. Raven. 1968. Covert categories and Folk taxonomies. American Anthropologist 70(2):290-299.

Berlin B., D.E. Breedlove \& P.H. Raven. 1973. General principles of classification and nomenclature in folk biology. American Anthropologist 75:214-242.

Biber, D., S. Conrad \& R. Reppen. 1998. Corpus Linguistics. Investigating language structure and use. University of Cambridge Press, Cambridge, U.K.

Boster, J. 1987. Agreement between biological classification system is not dependent on cultural transmission. American Anthopologist 89:914-919.

Boster, J., B. Berlin \& J.P. O'Neil. 1986. The correspondence of Jivaroan to scientific ornitology. American Anthropologist 88(3):569-583. 


\section{Savo et al. - "Modern Linnaeus": A class exercise on plant nomenclature and 229 taxonomy in comparison with a previous experiment}

Breda, N. 1995. Tassonomie botaniche popolari nei palù del Quartier del Piave (TV). Quaderni di Semantica 16:159-168.

Brown, C.H. 1974. Unique beginners and covert categories in folk biological taxonomies. American Anthropologist 76(2):325-327.

Brown, C.H. 1977. Folk botanical life- forms: Their universality and growth. American Anthropologist 79(2): 317342.

Buck, C.D. 1949. A Dictionary of Selected Synonyms in the Principal Indo-European Languages. University of Chicago Press, Chicago, Illinois.

Bulmer, R. 1967. Why is the cassowary not a bird? A problem of zoological taxonomy among the karam of the New Guinea Highlands. Man 2(1):1-25.

Castiglioni, L. \& S. Mariotti. 1996. Vocabolario della lingua latina. Third Edition. Loescher, Milan, Italy.

Conklin, H.C. 1969. Lexicographical treatment of folk taxonomies. Pp. 41-59 in Cognitive Anthropology. Edited by S.A. Tyler. Holt, Rinehart and Winston, New York.

Conti, F., G. Abbate, A. Alessandrini \& C. Blasi. 2005. An Annoted Checklist of Italian Flora. Ministero dell'Ambiente e della Tutela del Territorio. Dip. di Biologia vegetale Università di Roma "La Sapienza". Fratelli Palombi Editore, Rome.

Conti, F., A. Alessandrini, G. Bacchetta, E. Banfi, G. Barberis, F. Bartolucci, L. Bernardo, S. Bonacquisti, D. Bouvet, M. Bovio, G. Brusa, E. Del Guacchio, B. Foggi, S. Frattini, G. Galasso, L. Gallo, C. Gangale, G. Gottschlich, P. Grunanger, L. Gubellini, G. liriti, D. Lucarini, D. Marchetti, B. Moraldo, L. Peruzzi, L. Poldini, F. Prosser, M. Raffaelli, A. Santangelo, E. Scassellati, S. Scortegagna, F. Selvi, A. Soldano, D. Tinti, D. Ubaldi, D. Uzunov \& M. Vidali. 2007. Integrazioni alla checklist della flora vascolare italiana. Natura Vicentina 10:5-74.

Diamond, J.M. 1966. Zoological classification system of primitive people. Science 151:1102-1104.

Dwyer, P.D. 2005. Ethnoclassification, ethnoecology and the imagination. Journal de la Société des Océanistes 120-121(1/2):11-25.

Garzanti Linguistica online. http://garzantilinguistica.sapere.it.

Hiepko, P. 2006. Eipo plant nomenclature and classification compared with other folk taxonomic systems. Willdenowia 36:447-453.
Holmgren, P.K. \& N.H. Holmgren. 1998 [continuously updated]. Index Herbariorum: A global directory of public herbaria and associated staff. New York Botanical Garden's Virtual Herbarium. http://sweetgum.nybg.org/ih/.

Hunn, E.S. 1975. A measure of the degree of correspondence of folk to scientific biological classification. American Ethnologist 2:309-327.

Kay, P. 1971. On taxonomy and semantic contrast. Language 47:866-887.

Lau, Y.H., W.C. McClatchey, D. Reedy, A.K. Chock, K.W. Bridges \& Z. Ritchey. 2009. Are our students taxonomically challenged or not? Ethnobotany Research \& Applications 7:29-37.

Maddalon, M. 1995. Biotassonomie e categorie cognitive. Proposte di analisi lessicale per il repertorio fitonomico. Proceeding of the "XXI Convegno di Linguistica e Filologia Romanza". Palermo, Settembre 1995. Bruxelles.

Maddalon, M. 1998. Conoscere, riconoscere e chiamare. Riflessioni problematiche sulle etnoclassificazioni biologiche. Quaderni di Semantica 2:213-282.

Merriam-Webster Online Dictionary. www.merriam-webster.com.

Paolucci, L. 1926. Sul significato dei nomi volgari attribuiti agli animali e alle piante. Rendiconti Ist. Marchig. Di Scienze, Lettere e Arti (II, III, IV), Ancona.

Pignatti, S. 2003. Flora d'Italia. Edagricole, Bologna.

Raven, P.H., B. Berlin \& D.E. Breedlove. 1971. The origins of taxonomy. Science 174:1210-1213.

Rocci, L. 2002. Vocabolario Greco-Italiano. Dante Alighieri Editore, Florence.

Slangopedia, Italian Slang Dictionary online. http://temi. repubblica.it/espresso-slangopedia/.

Treccani Dizionario Enciclopedia online. www.treccani.it/ portale/opencms/Portale/homePage.html.

Tropicos.org. 2009. Missouri Botanical Garden. 18 Sept 2009. www.tropicos.org.

Trumper, J., M. Maddalon, M.T. Vigolo \& N. Misiti. 1999. II possibile ruolo della linguistica in rapporto ai saperi naturalistici. Quaderni di Semantica 20(1):147-157.

Trumper J. \& M.T. Vigolo. 1995. I/ Veneto Centrale Problemi di classificazione dialettale e di fitonimia. Centro Studio per la Dialettologia Italiana "O. Parlangeli". Consiglio Na- 
zionale delle Ricerche - the National Research Council of Italy (CNR), Italy.

Walters, S.M., J.C.M. Alexander, P.G. Barnes, F.M. Bennell, J.J. Bos, A. Brady, C.D. Brickell, E.J. Campbell, C.J. Couer, J. Cullen, S.J.M. Droop, P.S. Green, C. Grey-
Wilson, V.H. Heywood, P.-M. Jorgensen, S.L. Jury, S.G. Knees, A.C. Leslie, V.A. Mathews, N.K.B. Robson, D.O. Wijnands \& P.F. Yeo. 1986-2000. Editors of The European Garden Flora. Cambridge University Press, Cambridge, U.K. 


\section{Savo et al. - "Modern Linnaeus": A class exercise on plant nomenclature and 231 taxonomy in comparison with a previous experiment}

Appendix 1. Plants species used in the class experiment.

\begin{tabular}{|c|c|}
\hline Number & Species \\
\hline 1. & Juncus inflexus L. \\
\hline 2. & Arum italicum Mill. subsp. italicum \\
\hline 3. & Alliaria petiolata (M. Bieb.) Cavara \& Grande \\
\hline 4. & Solanum melongena $\mathrm{L}$. \\
\hline 5. & Euphorbia helioscopia L. subsp. helioscopia \\
\hline 6. & Quercus ilex L. subsp. ilex \\
\hline 7. & Teucrium fruticans L. subsp. fruticans \\
\hline 8. & $\begin{array}{l}\text { Callistemon viminalis (Sol. ex Gaertn.) } \\
\text { G. Don }\end{array}$ \\
\hline 9. & Calendula arvensis $\mathrm{L}$. \\
\hline 10. & Mentha suaveolens Ehrh. s.I. \\
\hline 11. & Solanum tuberosum L. \\
\hline 12. & Ruscus aculeatus L. \\
\hline 13. & Phragmites australis (Cav.) Trin. ex Steud. \\
\hline 14. & Brassica oleracea L. var. gongylodes L. \\
\hline 15. & Rosmarinus officinalis L. \\
\hline 16. & Geranium molle L. \\
\hline 17. & Ocimum basilicum L. \\
\hline 18. & Brassica oleracea L. var. sabauda L. \\
\hline 19. & Helianthus annuus L. \\
\hline 20. & Trifolium pratense L. \\
\hline
\end{tabular}

\begin{tabular}{|r|l|}
\hline Number & Species \\
\hline 21. & Sherardia arvensis L. \\
\hline 22. & Ranunculus bulbosus L. \\
\hline 23. & Pinus nigra Arnold subsp. nigra \\
\hline 24. & Carex acuta L. \\
\hline 25. & Ornithogalum umbellatum L. \\
\hline 26. & Laurus nobilis L. \\
\hline 27. & Silene latifolia Poir. subsp. alba (Mill.) \\
\hline 28. & Geronica persica Poir. \\
\hline 29. & Asparagus myriocladus Baker \\
\hline 30. & Bellevalia romana Rchb. \\
\hline 31. & Lamium maculatum L. \\
\hline 32. & Sonchus asper (L.) Hill s.I. \\
\hline 33. & Erodium moschatum (L.) L'Hér. ex Aiton \\
\hline 34. & Silene gallica L. \\
\hline 35. & Lavandula dentata L. \\
\hline 36. & Hedera helix L. s.I. \\
\hline 37. & Viburnum tinus L. \\
\hline 38. & Gleditsia sinensis Lam. \\
\hline 39. & Lamiastrum galeobdolon L. \\
\hline 40. & $\begin{array}{l}\text { Hordeum murinum subsp. leporinum (Link) } \\
\text { Arcang. }\end{array}$ \\
\hline
\end{tabular}


Appendix 2. Definitions of the term categories on which was based the discrimination of names, adjectives and plant parts.

\begin{tabular}{|c|c|}
\hline Categories & Definition of the term category/Criteria of assignement \\
\hline Actions & Verbs \\
\hline Adjectives & All terms defined as adjectives \\
\hline Animal/human parts & $\begin{array}{l}\text { All terms which can be referred as animal or human parts (excluding animals and peo- } \\
\text { ple) }\end{array}$ \\
\hline Animals & $\begin{array}{l}\text { Common names of animals and terms referring to animal species (not immaginative } \\
\text { ones) }\end{array}$ \\
\hline Art & Terms related to art expressions: art objects, art styles, art trends \\
\hline Associations & Terms referring to group or associations of people \\
\hline Composed terms & Terms which may be easily and obviously divided in two parts \\
\hline $\begin{array}{l}\text { Constructions, inventions } \\
\text { and technologies }\end{array}$ & Terms referring to Constructions, inventions and technologies \\
\hline Cosmetics and toiletries & Terms referring to objects and preparations used as cosmetics or for cosmetic purposes. \\
\hline Decorations & Terms referring to items which are commonly used for decorative purposes \\
\hline Descriptives & Terms referring to abstract concepts \\
\hline Events & Names of festivities, events, celebrations \\
\hline Exclamations & Exclamations \\
\hline Excrements & Terms referring to excrements \\
\hline Experiences & Terms referring to emotional experiences \\
\hline Explosives & Terms referring to explosives (e.g. fireworks) \\
\hline Fabrics & Terms referring to the different kind of fabrics, textile materials \\
\hline $\begin{array}{l}\text { Food, beverages and food } \\
\text { plants }\end{array}$ & $\begin{array}{l}\text { Plants commonly used as food and other kinds of food and beverages, included dishes } \\
\text { and preparations }\end{array}$ \\
\hline Hairstyles & Terms referring to hairstyles \\
\hline $\begin{array}{l}\text { Medicine and Medical } \\
\text { conditions }\end{array}$ & Terms referring to drugs, diseases, medicines, etc. \\
\hline Microorganisms & Specific and generic names of microorganisms \\
\hline Military operations & Terms referring to military operations \\
\hline Musical instruments & Terms referring to musical instruments \\
\hline Names & Proper names of people, brands, titles or movies, characters of Cartoons, Comics, Tales. \\
\hline Natural inanimate objects & $\begin{array}{l}\text { Terms referring to inanimate objects which are not human products, as well as natural } \\
\text { phenomena }\end{array}$ \\
\hline Numbers & Numbers \\
\hline Objects & $\begin{array}{l}\text { Terms defining different kind of objects which can not be included in other categories as } \\
\text { the ones of tools and utensils or technical instruments, Constructions, inventions and } \\
\text { technologies and Ship parts. }\end{array}$ \\
\hline People & Terms which design human beings, excluding proper names of people \\
\hline Phrases & Long phrases which include a verb \\
\hline Places & Terms referring to places, locations, cities etc. \\
\hline Plant parts & All terms which can be referred to plant parts \\
\hline Plant types & Terms referring to life forms of plants \\
\hline Plants & Common names of plants and terms referring to plant species (not immaginative ones) \\
\hline
\end{tabular}


Savo et al. - "Modern Linnaeus": A class exercise on plant nomenclature and 233 taxonomy in comparison with a previous experiment

\begin{tabular}{|c|c|}
\hline Categories & Definition of the term category/Criteria of assignement \\
\hline $\begin{array}{l}\text { Pronouns preposition or } \\
\text { adverbs }\end{array}$ & Pronouns preposition or adverbs \\
\hline Punctuation marks & Punctuation marks \\
\hline Song titles & Well recognizable song titles \\
\hline Sound & Onomatopoeic terms \\
\hline Sports & Terms referring to sports and outdoor activities \\
\hline Titles & Titles of people \\
\hline Tools and utensils & Terms defining different kind of tools, utensils or technical instruments \\
\hline Unknown & $\begin{array}{l}\text { Terms which are not reported by dictionaries or which are not well known "new" terms, } \\
\text { imaginary names }\end{array}$ \\
\hline Vocations & Activities which usually are motivated by a vocation (as for example, priests, policemen) \\
\hline \multicolumn{2}{|l|}{ Adjectives } \\
\hline Color & All adjectives describing the color \\
\hline Ethnicity & Adjectives which indicate the cultural provenience \\
\hline Feeling & Mental conditions, feelings and states of the mind \\
\hline Location & Adjectives which indicate the geographical or spatial position \\
\hline Pattern & Adjectives describing the disposition of elements \\
\hline Physical condition & States of the body and features of the body (considering also resemblance with animals) \\
\hline Quantity & Adjectives which quantify the referring term \\
\hline Shape & All adjectives describing the spatial form \\
\hline Size & All adjectives related to the extent of the referred thing \\
\hline Smell & Adjectives describing smell sensations \\
\hline Taste & Adjectives describing taste sensations \\
\hline Texture & All adjectives describing or related the tactile feature \\
\hline Undefinable & All adjectives which were not classifiable in other adjective categories \\
\hline \multicolumn{2}{|l|}{ Plant Parts } \\
\hline Bark & Bark and bark parts \\
\hline Branch & Branches \\
\hline Bud & Buds and apices \\
\hline Flower & Flowers and flower parts and strucutres \\
\hline Fruit & Fruits, false fruits \\
\hline Leaf & Leaves \\
\hline Root & Roots and hypogean apparata (even if stem parts, e.g. tubers) \\
\hline Seed & Seeds and seed types \\
\hline Stem & Stem and parts of the stem \\
\hline Thorn & Thorn \\
\hline
\end{tabular}


